\title{
Bats of Vieques National Wildlife Refuge, Puerto Rico, Greater Antilles
}

\author{
Isha R. Alexander and Keith Geluso* \\ University of Nebraska at Kearney, Department of Biology. Kearney, NE 68849, USA \\ * Corresponding author: E-mail: gelusok1@unk.edu
}

\begin{abstract}
Herein, we present captures of bats from Vieques, a small subtropical island located southeast of Puerto Rico. We captured 82 individuals representing 4 species, including 59 Noctilio leporinus, 9 Artibeus jamaicensis, 9 Molossus molossus, and 5 Stenoderma rufum. All S. rufum and M. molossus were captured in subtropical moist forests, whereas both $N$. leporinus and A. jamaicensis were captured in both subtropical moist and dry forests. Sternoderma rufum is an endemic species of concern in the region. Vieques represents only the 5 th island where this relatively rare species has been captured in the past 30 years. Conservation of subtropical moist forests on Vieques likely is important for the conservation and management of $S$. rufum and additional information about the natural history of all bats is warranted on Vieques.
\end{abstract}

\section{INTRODUCTION}

Vieques is a small subtropical island located $9.7 \mathrm{~km}$ from the southeastern coast of Puerto Rico in the Greater Antilles. Little published information exists on the distribution and habitat associations of bats on Vieques compared to bats on the nearby island of Puerto Rico (Gannon et al. 2005 and references therein). To date, four species of bats have been reported from Vieques including the greater bulldog bat (Noctilio leporinus Linnaeus, 1758), Jamaican fruit-eating bat (Artibeus jamaicensis Leach, 1821), Pallas's mastiff bat (Molossus molossus Pallas, 1766), and red fruit bat (Stenoderma rufum Desmarest, 1820; Gannon et al. 2005). To our knowledge, only M. molossus and $N$. leporinus have a single specific published locality of occurrence on Vieques, whereas for all other species nothing has been published yet on habitat associations.

Stenoderma rufum is a species of concern because it is an Antilles endemic (IUCN 2011). To date, only limited information is known for this species throughout its restricted distribution (Genoways and Baker 1972; Gannon et al. 2005). Puerto Rico represents the only island where it is captured commonly, thus where much of the information regarding its life history originates (Gannon and Willig 1994). Stenoderma rufum also occurs on the islands of St. Thomas and St. John (Genoways and Baker 1972; Bacle et al. 2008), and a single female was captured in St. Croix in 2004 (Kwiecinski and Coles 2007). On Vieques, Gannon et al. (2005) only reported "a juvenile red fig-eating bat was captured recently" on the island.

Herein, we report on the localities of occurrence and habitat associations for bats on Vieques. Our data will further provide baseline data for future conservation efforts and management of forests on Vieques and hopefully lead to more research on S. rufum. Limited prior research on bats on Vieques likely reflects that much of the island has had restricted access reflecting its former use as a U.S. Navy training facility for about six decades until 2003.

\section{Materials AND Methods}

\section{Study site}

We sampled bats at six sites at the Vieques National Wildlife Refuge (VNWR), Vieques, Puerto Rico. The refuge occupies $54 \%$ of the island $(7,191$ of $13,403 \mathrm{ha})$ and contains both subtropical dry and subtropical moist forests. Of our six sites, three were located in subtropical moist forests on the western side of the island (Boat

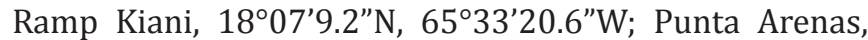
$18^{\circ} 06^{\prime} 51.6^{\prime \prime} \mathrm{N}, 65^{\circ} 34^{\prime} 32.2^{\prime \prime} \mathrm{W}$; Punta Arenas $18^{\circ} 06^{\prime} 35.8^{\prime \prime} \mathrm{N}$, $65^{\circ} 34^{\prime} 30.4^{\prime \prime} \mathrm{W}$ ), and three were located in subtropical dry forests in south-central parts of the island (Playuela, $18^{\circ} 06^{\prime} 37.7^{\prime \prime} \mathrm{N}, 65^{\circ} 24^{\prime} 59.5^{\prime \prime} \mathrm{W}$; Bahía de la Chiva Bridge, $18^{\circ} 06^{\prime} 46.7^{\prime \prime} \mathrm{N}, 65^{\circ} 23^{\prime} 29.6^{\prime \prime} \mathrm{W}$; Playa Plata, 1807’03.4”N, $65^{\circ} 22^{\prime} 36.0^{\prime \prime} \mathrm{W}$ ).

\section{Sampling technique}

We placed four 12-m mist nets (AviNet Inc., Dryden, NY, USA) at sites at dusk each evening at ground level along forest edges. Once bats were removed from nets, we placed each separately in a holding container. Next, we weighed each individual within $1 \mathrm{~h}$ of capture; measured length of forearm, tibia, tail, and ear with digital calipers; and recorded sex. All bats were released at the site of capture; a voucher photograph was taken of each species. We visited each site twice to capture bats, once during the dry season (25 June-1 July 2008) and once during the wet season (1-13 September 2008) for a total of 48 net nights. Due to the sensitive status of bats on VNWR, we documented species with photographic vouchers during our survey to secure records of occurrence on the island (see Figure 1). The four bat species on Vieques were identified by the following characteristics as well as others not listed here (see Gannon et al. 2005 for further details on species attributes): $N$. leporinus has long legs, enlarged hind feet and claws, and split upper lip; A. jamaicensis has a large-sized nose leaf and large overall size for fruiteating bats in the region; $S$. rufum contains white patches of fur below the ear and on the shoulder, large nose leaf, and medium-sized forearm lengths for fruit-eating bats in the region; and M. molossus lacks wrinkles on the upper lip 
and contains a partially free tail extending beyond the tail membrane.

The project was sponsored by the United States Fish and Wildlife Service at VNWR. Our capture and handling procedures of bats were approved by the Institutional Animal Care and Use Committee of the University of Nebraska at Kearney (IACUC \# 060208). Coordinates of sites were obtained with hand-held global positioning units (Garmin GPSMAP 76S, Garmin Ltd, Kansas, USA) using datum WGS 84.

\section{RESULTS AND Discussion}

We captured 82 bats representing four species in mist nets at ground level (Table 1, Figure 1, Appendix). The most common species was $N$. leporinus, with 59 individuals representing $72 \%$ of captures. Nine $A$. jamaicensis and $9 \mathrm{M}$. molossus also were captured at sites, each representing $11 \%$ of captures. Stenoderma rufum was the least frequently captured species, with 5 individuals representing $6 \%$ of captures. All S. rufum and A. jamaicensis were male and all M. molossus were female. Male $N$. leporinus were captured more frequently (71\%) than females and were consistently larger than females (Table 2). Details of body weight, length of tibia, tail, ear, and forearm are summarized for each species in Table 2.

All S. rufum and M. molossus were captured in subtropical moist forests of the island whereas $N$. leporinus and $A$. jamaicensis were captured in both subtropical moist and dry forests. Dominant species of plants by visual estimation where S. rufum was captured consisted of $75 \%$ Cocos nucifera Linneaus, 10\% Coccoloba uvifera (Linneaus) Linneaus, 5\% Sansevieria trisfaciata Prain, 5\% Leucaena leucocephala (Lamark) De Wit, and 5\% Bursera simaruba (Linneaus) Sargent. At this site, the ocean was about 44 $\mathrm{m}$ to the west, and mangroves (mainly Rhizophora mangle (Linneaus) and Avicennia germinans (Linneaus) Linneaus) were a few hundred meters to the east and southeast. The highest point on Vieques (Monte Pirata, 301 m elevation) was $3 \mathrm{~km}$ southeast of this location.

Bats are important ecological components of tropical ecosystems because they provide vital functions such as pollination and seed dispersal for many plants (Humphrey and Bonaccorso 1979; Charles-Dominique 1986; Gannon and Willig 1994). Bats on Vieques are the only native mammals (Gannon and Willig 1992; 1997), and species such as $A$. jamaicensis and $S$. rufum likely provide these ecological services for plants after disturbances such as hurricanes. Puerto Rico contains 13 extant species of bats with only four species being reported from the nearby island of Vieques (Gannon et al. 2005). During our limited survey, we documented the four species previously reported from the island (Gannon et al. 2005). Although few species occur on Vieques, one Antilles endemic, S. rufum, does inhabit this small island but occupies a different habitat than on Puerto Rico.

Based on the equation, $S=2.137 \times \mathrm{A}^{0.214}$ for species richness (S) of bats on Antillean islands (Fig. 7 in Gannon et al. 2005), six species of bats should occur on Vieques based on its area (A); however, a species/area curve based on bat fauna of the West Indies shows that Vieques (area of $132 \mathrm{~km}^{2}$ ) should contain about four species of bats
(Genoways et al. 2007). Thus, the species known to occur on Vieques are at or below predicted values for islands of similar size. With additional sampling, we suspect that additional bats will be reported on Vieques due to the proximity of this island to the larger island of Puerto Rico with its greater diversity of species. Although our limited survey provides new localities and habitat associations for bats on Vieques, our brief mist-net survey needs to be extended over a period of years with a longer duration of survey effort to better understand the species composition on the island (Larsen et al. 2007).

On Puerto Rico, most of its 13 species roost in caves (Rodríguez-Durán 1998; Gannon et al. 2005), but with few caves or cave-like structures on Vieques, many caveobligate species likely will not be observed on the island even with additional surveys. For the four species known from Vieques, roost sites commonly used by each species are available. Although $N$. leporinus and A. jamaicensis roost in caves, both species also commonly roost in trees (Hood and Jones 1984; Kunz and McCracken 1996). We captured 51 of $59 \mathrm{~N}$. leporinus near a suspected tree roost at Playuela in an area consisting mainly of red mangroves (R. mangle). On Puerto Rico, S. rufum roosts in foliage and M. molossus commonly roosts in buildings (Gannon et al. 2005); both these types of roosts also occur on Vieques. We surmise that $S$. rufum roosts in the foliage of trees on Vieques, as it does on Puerto Rico (Gannon and Willig 1997), but likely in different tree species because our captures were near sea level in a different habitat than where S. rufum was studied in Puerto Rico.

Given their proximity and abundance on Puerto Rico, the absence of several species of bats on Vieques is notable. The Antillean fruit-eating bat (Brachyphylla cavernarum Gray, 1834) is a robust bat common throughout the region (Swanepoel and Genoways 1983; Gannon et al. 2005) known for its catholic roosting and dietary habits (Swanepoel and Genoways 1983), but this species is a cave-obligate species throughout the region (see Swanepoel and Genoways 1983). Additional species of bats that may be documented on Vieques with further survey efforts include the big brown bat (Eptesicus fuscus (Palisot de Beauvois, 1796)), eastern red bat (Lasiurus borealis (Müller 1776)), and Brazilian free-tailed bat (Tadarida brasiliensis (I. Geoffroy Saint-Hilaire, 1824)).

Hurricanes have been shown to be detrimental to $S$. rufum in Puerto Rico (Gannon and Willig 1994; Jones et al. 2001). For example, after hurricane Hugo passed over Puerto Rico, captures of S. rufum decreased $80 \%$ and it took five years for populations to rebound (Gannon et al. 2005). Hurricanes may affect habitat and reproduction for $S$. rufum and other bats on Vieques in a similar manner. Hurricane-aided dispersal of individual bats from Puerto Rico or the Virgin Islands to Vieques may affect the genetic richness for $S$. rufum on the island, as was demonstrated with A.jamaicensis on Grand Cayman (Fleming and Murray 2009). Moreover, Fleming and Murray (2009) suggested that the occurrence of $S$. rufum on two of the Virgin Islands east of Puerto Rico, St. John and St. Croix, potentially may have been aided by hurricanes.

\section{Conservation priority}

Stenoderma rufum was observed in subtropical moist 
forests at low elevations on Vieques during our limited survey, thus conservation of subtropical moist forests on Vieques appears important for the persistence of this species. In contrast, most $S$. rufum have been captured from the montane Luquillo Experimental Forest on Puerto Rico (Gannon and Willig 1994; Gannon et al. 2005). It is therefore unclear as to what type of forest constitutes a preferred habitat and why S. rufum was only observed at lower elevations and in drier habitats on Vieques than on Puerto Rico. Additional inventory surveys along with the radio-tracking of bats is warranted to better understand the ecology and conservation demands of this species on Vieques and how those differ from populations on Puerto Rico. Determination of the subspecific status of $S$. rufum on Vieques also is warranted to further aid in conservation efforts.

TABLE 1. Summary of bats captured in mist nets on the island of Vieques, Puerto Rico, from 24 June to 13 September 2008 . Three sites were in a subtropical moist forest on the west side of the island (Moist) and 3 sites in a subtropical dry forest on the south-central part of the island (Dry). Number of sites represents the number of sites where the species were captured; total sites visited equaled six.

\begin{tabular}{lccccc}
\hline & \multicolumn{2}{l}{ No. of individuals } & \multicolumn{2}{l}{ Percentage of captures by habitat } & \\
\hline Species & Male & Female & Dry & Moist & No. of sites \\
Noctilio leporinus & 42 & 17 & $68.3 \%$ & $3.6 \%$ & 4 \\
Artibeus jamaicensis & 9 & -- & -- & $5.0 \%$ & 4 \\
Molossus molossus & -- & 9 & $9.8 \%$ & $1.2 \%$ & 2 \\
Stenoderma rufum & 5 & -- & -- & $6.1 \%$ & 1 \\
\hline Totals & 56 & 26 & $87.9 \%$ & $12.1 \%$ & \\
\hline
\end{tabular}
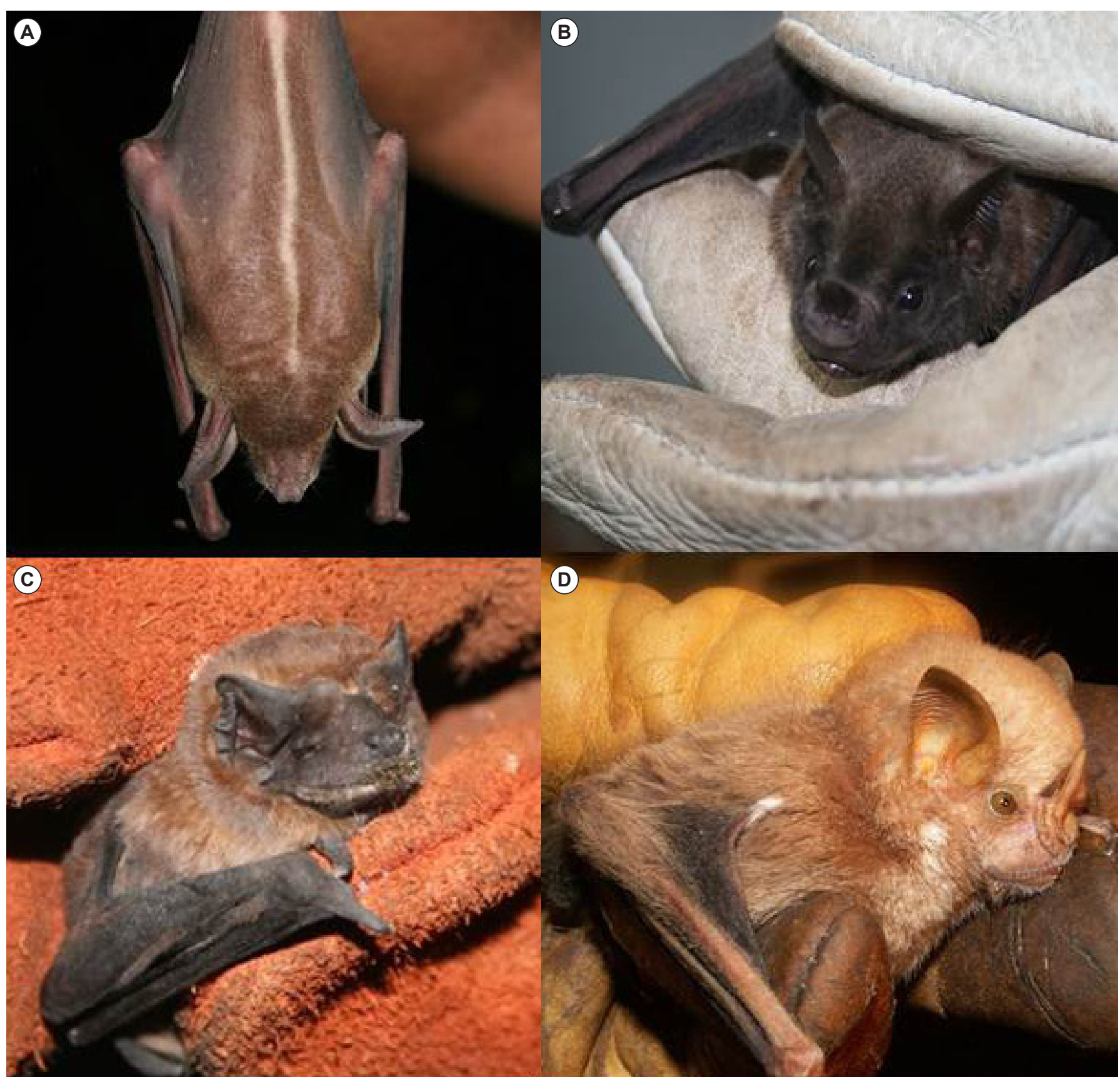

FigURE 1. Four species of bats observed from the island of Vieques, Puerto Rico, in 2008. A) Noctilio leporinus, 8 September, Playuela; B) Artibeus jamaicensis, 25 June, Bahía de la Chiva; C) Molossus molossus, 27 June, Punta Arenas; D) Stenoderma rufum, 29 June, Punta Arenas. 
TABLE 2. Mean body weight (g) and mean length (mm) of forearm, tail, tibia, and ear of bats captured on Vieques, Puerto Rico, from 24 June 2008 to 13 September 2008. All measurements were taken within 1 hour of capture. Numbers in parentheses represent sample size, and numbers below means represent minimum and maximum values.

\begin{tabular}{|c|c|c|c|c|c|c|c|c|c|c|}
\hline \multirow{2}{*}{ Species } & \multicolumn{2}{|c|}{ Body weight (g) } & \multicolumn{2}{|c|}{ Forearm length (mm) } & \multicolumn{2}{|c|}{ Tail length (mm) } & \multicolumn{2}{|c|}{ Tibia length (mm) } & \multicolumn{2}{|c|}{ Ear length (mm) } \\
\hline & Male & Female & Male & Female & Male & Female & Male & Female & Male & Female \\
\hline \multirow{2}{*}{ Noctilio leporinus } & $67.3(42)$ & $61.9(17)$ & $83.4(42)$ & $83.2(17)$ & $25.2(42)$ & $26.1(17)$ & $39.2(42)$ & $38.1(17)$ & $22.4(42)$ & $22.8(17)$ \\
\hline & $49.0-85.0$ & $54.5-72.0$ & $78.6-86.6$ & $80.4-85.8$ & $20.9-32.7$ & $22.0-30.6$ & $36.2-48.8$ & $34.6-41.8$ & $13.6-26.5$ & $15.4-26.6$ \\
\hline Artibeusjamaicensis & $\begin{array}{c}47.1(9) \\
42.0-56.0\end{array}$ & -- & $\begin{array}{c}57.4(9) \\
52.3-61.6\end{array}$ & -- & -- & -- & $\begin{array}{c}23.9(9) \\
21.9-26.1\end{array}$ & -- & $\begin{array}{c}13.6(9) \\
10.8-16.8\end{array}$ & -- \\
\hline Molossus molossus & -- & $\begin{array}{c}18.2(9) \\
14.5-24.0\end{array}$ & -- & $\begin{array}{c}38.3(9) \\
35.3-40.6\end{array}$ & -- & $\begin{array}{c}33.6(9) \\
30.5-39.1\end{array}$ & -- & $\begin{array}{c}13.1(9) \\
10.3-14.8\end{array}$ & -- & $\begin{array}{l}8.1(9) \\
4.9-9.3\end{array}$ \\
\hline
\end{tabular}

ACKNOWLEDGMENTS: We thank Mike Barandiaran (U.S. Fish and Wildlife Service, VNWR) for assistance in facilitating this project, help in the field, and providing logistical supplies and materials. We thank Matthew Connolly (Refuge Manager VNWR) for support of the project. We also thank Frederick Abbot, Gabriel Benítez, Morales Benítez, Erick Cantaroan, José Luis Herrera, David Nieves, Limary Ramírez, Martin Ramos, Rob Ríos, Misael Rivera, Francheska Ruiz-Canino, and other volunteers and employees for assistance in the field. Anonymous reviewers and M. Gannon improved the content and flow of earlier versions of this manuscript.

\section{Literature Cited}

Bacle, J.-P., K.C. Lindsay and G.G. Kwiecinski. 2008. Bats of St. Thomas and St. John, U.S. Virgin Islands: Priority conservation measures for species of greatest concern. Island Resources Foundation, Occasional Papers 60: 1-13.

Charles-Dominique, P. 1986. Inter-relations between frugivorous vertebrates and pioneer plants: Cecropia, birds and bats in French Guyana; p. 119-135 In A. Estrada and T.H. Fleming (eds.). Frugivores and seed dispersal. Boston: Dr. W. Junk Publishers.

Fleming, T.H. and K.L. Murray. 2009. Population and genetic consequences of hurricanes for three species of West Indian phyllostomid bats. Biotropica 41(2):250-256.

Gannon, M.R. and M.R. Willig. 1992. Bat reproduction in the Luquillo experimental forest of Puerto Rico. Southwestern Naturalist 37(4):414-419.

Gannon, M.R. and M.R. Willig. 1994. The effects of hurricane Hugo on bats of the Luquillo experimental forest of Puerto Rico. Biotropica 26(3):320-331.

Gannon, M.R. and M.R. Willig. 1997. The effect of lunar illumination on movement and activity of the red fig-eating bat (Stenoderma rufum). Biotropica 29(4):525-529.

Gannon, M.R., A. Kurta, A. Rodríques-Durán and M.R. Willig. 2005. Bats of Puerto Rico: An island focus and a Caribbean perspective. Lubbock, Texas: Texas Tech University Press. 239 p.

Genoways, H.H. and R.J. Baker. 1972. Stenoderma rufum. Mammalian Species 18:1-4.

Genoways, H.H., P.A. Larsen, S.C. Pedersen and J.J. Huebschman. 2007. Bats of Saba, Netherlands Antilles: a zoogeographic perspective. Acta Chiropterologica 9(1):97-114.

Hood, C.S. and J.K. Jones, Jr. 1984. Noctilio leporinus. Mammalian Species 216:1-7.

Humphrey, S.R. and F.J. Bonaccorso. 1979. Population and community ecology; p. 409-441 In R.J. Baker, J.K. Jones Jr. and D.C. Carter (eds.). Biology of the bats of the New World family Phyllostomatidae. Part III. Lubbock, Texas: Special Publications of the Texas Tech University No. 16.
IUCN (International Union for the Conservation of Nature). 2011. IUCN Red List of Threatened Species. Version 2011.2. Electronic database accessible at http://www.iucnredlist.org. Captured on 19 May 2012.

Jones, K.E., K.E. Barlow, N. Vaughan, A. Rodríguez-Durán and M.R. Gannon. 2001. Short-term impacts of extreme environmental disturbance on the bats of Puerto Rico. Animal Conservation 4(1):59-66.

Kunz, T.H. and G.F. McCracken. 1996. Tent and harems: apparent defense of foliage roosts by tent-making bats. Journal of Tropical Ecology 12(1):121-137.

Kwiecinski G.G. and W.C. Coles. 2007. Presence of Stenoderma rufum beyond the Puerto Rican bank. Texas Tech University, Occasional Papers of the Museum 266:1-9.

Larsen, R.J., K.A. Boegler, H.H. Genoways, W.P. Masefield, R.A. Kirsch and S.C. Pedersen. 2007. Mist netting bias, species accumulation curves, and the rediscovery of two bats on Montserrat (Lesser Antilles). Acto Chiropterologica 9(2):423-435.

Rodríguez-Durán, A. 1998. Nonrandom aggregations and distribution of cave-dwelling bats in Puerto Rico. Journal of Mammalogy 79(1):141146.

Swanepoel, P. and H.H. Genoways. 1983. Brachyphylla cavernarum. Mammalian Species 205:1-6.

RECEIVED: July 2012

ACCEPTED: January 2013

Published ONLINE: April 2013

EDITORIAL RESPONSIBILITY: Marcelo R. Nogueira

APPENDIX. Netting localities for bats in Vieques National Wildlife Refuge, Vieques (Puerto Rico) in 2008. Dates of capture are followed by parentheses containing the number of male and female individuals for each species. Abbreviations for species are as follows Noctilio leporinus (NOLE), Artibeus jamaicensis (ARJA), Molossus molossus (MOMO), and Stenoderma rufum (STRU).

Subtropical Dry Forests: Playuela, $1^{\circ} 06^{\prime} 37.7^{\prime \prime} \mathrm{N}, 065^{\circ} 24^{\prime} 59.5^{\prime \prime} \mathrm{W}$; 1

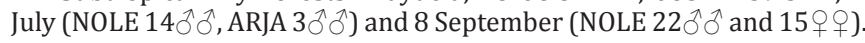
Bahía de la Chiva Bridge, 1806'46.7"N, 065²3'29.6”W; 25 June (ARJA 1 $\left.{ }^{\prime}\right)$ ) and 6 September (no bats). Playa Plata, $1^{\circ} 07^{\prime} 03.4^{\prime \prime} \mathrm{N}, 065^{\circ} 22^{\prime} 36.0^{\prime \prime} \mathrm{W}$; 30 June (no bats) and 4 September (NOLE $1 \delta^{\Uparrow}$ ).

Subtropical Moist Forests: Boat Ramp Kiani, $18^{\circ} 07^{\prime} 9.2^{\prime \prime} \mathrm{N}$ $065^{\circ} 33^{\prime} 20.6^{\prime \prime} \mathrm{W} ; 26$ June (no bats) and 2 September 2008 (no bats). Punta

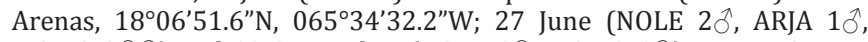
MOMO $3 \circ$ 이) and 10 September (NOLE 1ㅇ, MOMO 1ㅇ). Punta Arenas $18^{\circ} 06^{\prime} 35.8^{\prime \prime} \mathrm{N}, 065^{\circ} 34^{\prime} 30.4^{\prime \prime} \mathrm{W} ; 29$ June (NOLE $2{ }^{\prime}$, ARJA $2{ }^{\jmath}$, MOMO 5 우, STRU $5 \hat{\jmath}$ ) and 10 September (NOLE 1 , MOMO 1ㅇ). 